\title{
REKONSTRUKSI PERTANGGUNGJAWABAN PIDANA TERHADAP TINDAK PIDANA KORUPSI APBD YANG DILAKUKAN OLEH ANGGOTA DPRD
}

\author{
Noor Aziz Said \\ Fakultas Hukum Universitas Jenderal Soedirman Purwokerto \\ E-mail: noor.said@unsoed.ac.id
}

\begin{abstract}
Indonesia's national legal system based on modern law with a philosophy liberalism, individualism and rationalisme background of the nineteenth century in Europe (Penal Code), that contains the class characteristics. The characteristics of the national law classes imply of the Court as a judicial dictatorship. The existence of three different decision in terms of budget corruption committed by members of parliament, namely decision-free, loose and criminal verdict in the same case is proof of the dictatorship of the Court. To prevent the necessary expansion of the meaning of a judicial dictatorship legality principle, from the formal justice-procedural justice toward substantial material with 3-integral approach, the approach of juridical science religious, juridical contextual, and insightful approach to comparative/global recall the problem of corruption is an issue international. In addition it needs to be revisited Constitutional Court Decision No. 003/PUU-IV/2006 to be replaced with understanding the material unlawfully receiving AVAW as set forth in Supreme Court Jurisprudence No. $42 \mathrm{~K} / \mathrm{Kr} / 1965$ and also article 2 and article 5 of Law. 48 of 2009 and the possible penal settlement by mediation.
\end{abstract}

Keywords : modern law, judicial dictatorship, reconstruction of criminal responsibility, criminal acts of corruption.

\begin{abstract}
Abstrak
Sistem hukum nasional Indonesia berbasis hukum modern dengan latar belakang falasafah warisan abad XIX di Eropa (KUHP), yakni liberalisme, individualisme dan rationalisme yang mengandung ciriciri kelas. Ciri-ciri kelas hukum nasional berimplikasi kepada karakteristik Pengadilan sebagai judicial dictatorship. Adanya tiga putusan yang berbeda dalam hal tindak pidana korupsi APBD yang dilakukan oleh anggota DPRD, yakni putusan bebas, lepas dan putusan pidana dalam perkara yang sama merupakan bukti kediktatoran Pengadilan. Untuk mencegah timbulnya judicial dictatorship diperlukan perluasan makna asas legalitas, dari keadilan formal-prosedural menuju ke arah keadilan material-substansial dengan 3 pendekatan secara integral, yakni pendekatan yuridis keilmuan religius, yuridis kontekstual, dan pendekatan berwawasan komparatif/global mengingat masalah korupsi sudah merupakan isu internasional. Di samping itu perlu ditinjau kembali Putusan Mahkamah Konstitusi No. 003/PUU-IV/2006 untuk diganti pengertian melawan hukum materiil dengan menerima AVAW sebagaimana dimaksud dalam Yurisprudensi Mahkamah Agung No. 42 K/Kr/1965 dan juga pasal 2 dan pasal 5 UU No. 48 Tahun 2009 serta dimungkinkan penyelesaian dengan mediasi penal.
\end{abstract}

Kata Kunci: hukum modern, kediktatoran pengadilan, rekonstruksi pertanggungjawaban pidana, tindak pidana korupsi.

\section{Pendahuluan}

Proses pembangunan dapat menimbulkan kemajuan dalam kehidupan masyarakat, selain itu dapat juga mengakibatkan perubahan kondisi sosial masyarakat yang memiliki dampak negatif, terutama yang menyangkut masalah peningkatan tindak pidana yang merasahkan masyarakat. Salah satu tindak pidana yang dapat dikatakan fenomenal adalah masalah korupsi. Tindak pidana ini tidak hanya merugikan keuangan negara, tetapi juga merupakan pelanggaran terhadap hak-hak sosial dan ekonomi masyarakat. ${ }^{1}$ Oleh karena itu adalah benar apabila tindak pidana korupsi merupakan

E. Hartanti, 2007, Tindak Pidana Korupsi, Jakarta: Sinar Grafika, hlm. 1 
extra ordinary crime karena tindak pidana korupsi dapat merusak sendi-sendi kehidupan bermasyarakat, berbangsa dan bernegara serta mengganggu pertumbuhan ekonomi dan tujuan pembangunan nasional, yakni mewujudkan masyarakat yang adil dan makmur berdasarkan Pancasila dan UUD 1945 (Konsiderans UU No. 31 Tahun 1999).

Konvensi PBB Anti Korupsi, yakni United Nations Convention Against Corruption (UNCAC) 2003 mendeskripsikan masalah korupsi sudah merupakan ancaman serius terhadap stabilitas, keamanan masyarakat nasional dan internasional, telah melemahkan institusi, nilai-nilai demokrasi dan keadilan serta membahayakan pembangunan berkelanjutan mau pun penegakan hukum. UNCAC kemudian diratifikasi dengan UU No. 7 Tahun 2006 menimbulkan implikasi karakteristik dan substansi gabungan dua sistem hukum yaitu "civil law" dan "common law" sehingga akan berpengaruh kepada hukum positif yang mengatur tindak pidana korupsi di Indonesia. ${ }^{2}$

Di Indonesia, khususnya sejak berlakunya UU No. 22 Tahun 1999, praktek korupsi di Indonesia yang sebelumnya lebih banyak terjadi di ranah birokrasi dan perbankan, kini sudah merambah masuk ke lembaga legislatif. Terungkapnya kasus-kasus korupsi para anggota legislatif daerah ini seiring dengan dilaksanakannya otonomi daerah berdasarkan UU No. 22 Tahun 1999 yang salah satu tujuannya adalah lebih memberdayakan peran dan fungsi legislatif. Modus korupsi aktual yang sering terjadi di lembaga legislatif daerah diantaranya adalah penipuan terhadap anggaran dengan mengambil pos anggaran lain dengan maksud "menyembunyikan" nama pos yang mungkin dianggap terlalu mencolok atau mengada-ada; menciptakan anggaran baru yang sebenarnya tidak diatur dalam peraturan; mark up anggaran dengan

\footnotetext{
Lilik Mulyati, 2008, Politik Hukum Kebijakan Legislasi Pembalikan Beban Pembuktian Dalam Tindak Pidana Korupsi, Dalam Buku Berjudul: Bagir Manan Ilmuan dan Penegakan Hukum (Kenangan Sebuah Pengabdian), Jakarta: Mahkamah Agung Rl, hlm. 421. Lihat juga Shafrudin, "Pelaksanaan Politik Hukum Pidana dalam Penegakan Hukum Pidana di Indonesia", Jurnal Hukum Pro Justitia Vol. 27 No. 2 Oktober 2009 FH Unpar Bandung, hlm. 177-192.
}

melebihkan berbagai tunjangan (anggota dewan) yang telah diatur dalam UU; pengalokasian anggaran yang sebetulnya sama dengan anggaran lainnya (duplikasi anggaran); pembuatan anggaran tanpa perincian. Modus ini dilakukan dengan cara membuat anggaran dalam bentuk satuan tanpa diperinci lagi; menghilangkan pos anggaran; pengalihan anggaran yang seharusnya diberikan dalam bentuk jaminan asuransi menjadi dalam bentuk uang; bantuan berbentuk uang diubah barang dan mengurangi spesifikasinya; pengadaan barang dan jasa dengan cara di mark-up harga barang dan jasa dari harga pasar dan kolusi dengan Kontraktor; penghapusan inventaris dan asset Negara dengan cara memboyong inventaris kantor untuk kepentingan pribadi atau menjual inventaris kantor untuk kepentingan pribadi; pemotongan bantuan sosial atau subsidi (Sekolah, Panti Asuhan, Pesantren, dan lain-lain) melalui cara dengan menyunat dana bantuan yang dilakukan di setiap tingkatan meja; penyelenggaran dana proyek dengan cara mengambil dana proyek di luar ketentuan dan memotong dana proyek; dan proyek fisik fiktif dalam laporan tercantum tetapi di lapangan nihil tidak ada proyek. ${ }^{3}$

Perkara tindak pidana korupsi yang diajukan ke pengadilan yang dilakukan anggota DPRD (Provinsi, Kabupaten, dan Kota) pada dasarnya adalah sama, yakni penyusunan Perda APBD yang melanggar rambu-rambu hukum/peraturan perundang-undangan yang harus dipedomani dan penggunaan APBD yang melanggar ketentuan Perda APBD yang bersangkutan. Akan tetapi Mahkamah Agung RI (selanjutnya disingkat MA-

\footnotetext{
IGM Nurdjana, 2010, Sistem Hukum Pidana dan Bahaya Laten Korupsi : Perspektif Tegaknya Keadilan Melawan Mafia Hukum, Yogyakarta: Pustaka Pelajar, hlm.42-43. Baca juga La Sina, "Dampak dan Upaya Pemberantasan serta Pengawasan Korupsi di Indonesia", Jurnal Hukum Pro Justitia Vol. 26 No. 1 Januari 2008 FH Unpar Bandung, hlm. 39-51; Sjahruddin Rasul, "Penerapan Manajemen Berbasis Kinerja dalam Pemberantasan Korupsi”, Jurnal Hukum Pro Justitia Vol. 26 No. 1 Januari 2008 FH Unpar Bandung, hlm. 52-67; Frans Hendra Winarta, "Korupsi dan Hukum di Indonesia", Majalah Hukum Pro Justitia Tahun XIX No. 3 Juli 2001 FH Unpar Bandung, hlm. 46-58. Sebagai perbandingan, baca juga Ateng Syafrudin, "Tanggung Jawab Kepala Daerah Menurut UU No 22 Tahun 1999", Majalah Hukum Pro Justitia Tahun XIX No. 1 Januari 2001 FH Unpar Bandung, hlm. 3-4.
} 
RI) dalam menjatuhkan putusan terdapat tiga jenis putusan, yakni pidana (veroordeling), lepas dari segala tuntutan hukum (ontslag van alle rechtvervolging) dan putusan bebas (vrijspraak).

Timbulnya tiga putusan yang berbeda secara substansial berakibat (a) tidak terdapatnya kepastian hukum (formal dan material); (b) timbulnya penilaian bahwa putusan MARI bersifat diskriminatif; (c) menyentuh perasaan keadilan masyarakat; dan (d) dari segi hukum acara pidana/KUHAP, putusan-putusan yang berbeda memungkinkan untuk dijadikan alasan peninjauan kembali dimaksud dalam Pasal 263 KUHAP.

Dari segi sistem hukum, putusan yang berbeda-beda tersebut melanggar prinsipprinsip moral dari sistem hukum diantaranya adalah generality; intelligibility and clarity; avoidance of contradictions; congruence between official action and declared rule. ${ }^{4}$

Apabila ditinjau dari segi praktek peradilan, timbulnya tiga putusan MARI yang berbeda tersebut menimbulkan perbedaan persepsi dikalangan aparat penegak hukum yang kadangkadang menajam diantara Pengadilan, Kejaksaan, Polri dan Pengacara yang kesemuanya itu merupakan jajaran Integrated Criminal Justice System.

Tulisan ini akan membahas dua hal. Pertama, mengenai relevansi mempertahankan ataukah tidak terhadap putusan pengadilan yang telah ada mengenai pertanggungjawaban pidana pada tindak pidana korupsi APBD yang dilakukan oleh anggota DPRD; dan kedua, mengenai konstruksi pertanggungjawaban pidana dan administrasi terhadap tindak pidana korupsi $A P B D$ yang dilakukan oleh anggota DPRD

\footnotetext{
Ada delapan prinsip moral sistem hukum sebagaimana dikemukakan oleh Fuller : “.....eight requirements of "inner morality" of law from the very nature of legal system". The eight principles are : (1) generality; (2) promulgation; (3) prospective legal operation, i.e., generally prohibition of retroactive laws; (4) intelligibility and clarity; (5) avoidance of contradictions; (6) avoidance of impossible demands; (7) constancy of the law through time, i.e., avoidance of frequent changes; (8) congruence between official action and declared rule. Friedmann, W 1970, Legal Teory, New York: Columbia University Press, hlm. 16.
}

yang sesuai dengan kerangka sistem hukum nasional.

\section{Pembahasan \\ Karakteristik Hukum Modern}

Hukum dalam pandangan yang legalistik, hukum di identikkan dengan undang-undang. Sistem hukum dipandang sebagai "logische Geschlossenheit", sebagai suatu struktur tertutup yang logis, tidak bertentangan satu sama lain. Hukum dipandang sebagai seperangkat aturan-aturan yang diharapkan agar ditaati oleh para anggota masyarakat. ${ }^{5}$ Penggarapan hukum hanya berkisar pada bergumul dengan undangundang, jurisprudensi dan buku-buku pelajaran tentang hukum. Hukum menjadi tujuan sendiri (Selbstzweck). ${ }^{6}$

Pernyataan Sudarto di atas adalah berkaitan dengan asas legalitas, utamanya dalam hukum pidana. Asas legalitas yang mendasari sistem hukum modern menurut sejarahnya nyata berpijak kepada asas liberalisme, individualisme, dan rationalisme dengan tujuan memberi jaminan perlindungan kepada seorang terhadap kesewenang-wenangan penguasa demi kepastian hukum. Asas legalitas yang menuntut kepastian formal dengan keadilan sebagai unsur regulatif dan bukan kepastian materiil dengan keadilan sebagai unsur konstitutif tercermin dalam penegakan hukum pidana.

Mengenai ajaran positivisme-legalistik yang lazim disebut ajaran Analytical Legal Positivism yang dikemukakan oleh John Austin ${ }^{7}$ ini, patut dicatat pernyataan Satjipto Rahardjo, bahwa "fenomena korupsi yang dilakukan DPRD-DPRD di negeri ini sudah terlanjut merebak kemana-mana. Korupsi tidak hanya terjadi di DPRD Sumatera Barat tetapi juga "menyusul" dimana-mana, di hampir semua bagian negeri ini, di Jawa Tengah, Jawa Barat, Jawa Timur, Nusa Tenggara Barat, dan banyak lainnya. Korupsi di daerah-daerah itu biasa berdalih "sudah sesuai dengan prosedur" membenarkan

\footnotetext{
Sudarto, 1986, Hukum dan Hukum Pidana, Bandung: Alumni, hlm. 5

Ibid.

Lihat pembahasan lebih lanjut mengenai pemikiran Austin pada Theo Huijbers, 1990, Filsafat Hukum, Yogyakarta: Kanisius, hlm. 41-42.
} 
korupsi dengan alasan sesuai dengan prosedur adalah pereduksian makna proyek kultural raksasa yang namanya Negara Hukum secara luar biasa. Suatu pelecehan yang luar biasa. Menjalankan dan menegakkan hukum hanya dengan membaca prosedur adalah menjalankan hukum dengan kecerdasan rasional (IQ), yang hanya bisa memperhatikan proses-proses hukum secara linier dan masinal. ${ }^{8}$ Sampai hari ini cara berpikir dalam hukum relatif masih di kuasai warisan berpikir abad XIX yang positivitas-dogmatis. Berpikir seperti ini dapat di sejajarkan dengan berpikir berdasar kecerdasan rasional yang bersifat datar, logis, dan mendasarkan pada peraturan formal. Kredo yang digunakan adalah "peraturan dan logika" (rules and logic).

Pikiran (mind-set) positif-tekstual kurang lebih hanya akan "mengeja" suatu peraturan. Cara berpikir hukum seperti itu disini disebut "linier". Di sini kita bisa diingatkan kembali pada pendapat Paul Scholten, seorang pemikir hukum Belanda, yang mengatakan "hukum itu ada dalam UU, tetapi masih harus ditemukan". Maka menjadi salah sekaligus dangkal bila orang hanya "mengeja" peraturan.

Pola pikir "rules and logic" pada ajaran legalistik-positivistik menempatkan pengadilan sebagai corong undang-undang. Memang semangat liberal dan legalisme-positivistik yang sangat kuat di abad ke-19 itu memberikan landasan teori bagi munculnya pengadilan yang terisolasi dari dinamika masyarakat dimana pengadilan berada. Isolasi tersebut juga mengundang asosiasi ke arah kediktatoran pengadilan (judicial dictatorship). Oleh karena ia memutus semata-mata dengan mengingat apa yang menurut tafsirannya dikehendaki oleh hukum tanpa harus melibatkan kedalam atau mendengarkan dinamika masyarakat tersebut. Adalah benar adagium "lex dura sed tamen scripta" (hukum itu keras tetap begitulah sifat hukum tertulis). Kediktatoran pengadilan diperkuat oleh adagium "Res judicata pro veretate habitur" (putusan hakim harus dianggap benar

\footnotetext{
8 Satjipto Rahardjo, 2008, Membedah Hukum Progresif", Penerbit Buku Kompas, Jakarta. HIm 120-121.

9 Ibid.
}

sehingga mempunyai kekuatan mengikat sampai dibatalkan oleh pengadilan lain). ${ }^{10}$

Pertanggungjawaban pidana dalam hal tindak pidana korupsi, khususnya yang dilakukan oleh anggota DPRD selama ini masih mempertahankan ajaran positivisme-legalistik. Akibatnya, tak pelak pertanggungjawaban pidana demikian ini menimbulkan deskriminasi dalam penegakan hukum. Timbulnya tiga putusan MARI yang berbeda sebagaimana tersebut di atas adalah dampak negatif dari ajaran positivismelegalistik yang memang bertujuan mencapai kebenaran formal prosedural (dan jauh dari mencapai kebenaran substansial) yang menyebabkan penegakan hukum semakin terpuruk seperti dikatakan oleh Achmad Ali:

"Secara universal, jika kita ingin keluar dari situasi keterpurukan hukum, maka jawabannya adalah membebaskan diri dari belenggu positivism. Mengapa demikian? Karena dengan hanya mengandalkan teori dan pemahaman hukum secara legalistik-positivistis yang hanya berbasis pada peraturan tertulis (rule bound) belaka, maka kita takkan pernah mampu untuk menangkap hakikat kebenaran, karena baik dari historis maupun filosofi yang melahirkannya, ia memang tidak mau melihat atau mengakui hal itu" ${ }^{11}$

Muhammad Roem dalam catatan Sebastiaan Pompe pada tahun 1960 sudah mengingatkan gejala penurunan integritas Pengadilan, dengan ungkapan

"Corruption in the courts has begun. It is only a little so far, one or two judges. But it has begun and that is what is important. This beginning may well develop into something and more widespread"12.

Hasil penelitian The World Bank menunjukkan bahwa many lawyers feel no shame at offering sums of money to judges and

10 Ibid. Lihat dan bandingkan mengenai pemikiran hukum modern ini pada Muhammad Akib, "Refleksi Pemikiran Hukum Modern: Suatu Orientasi Menuju Paradigma Deep Ecology dalam Pengkajian Ilmu Hukum", Jurnal Hukum Pro Justitia Vol. 27 No. 2 Oktober 2009 FH Unpar Bandung, hlm. 155-168.

11 Achmad Ali, 2002, Keterpurukan Hukum di Indonesia, Jakarta: Ghalia Indonesia, hlm 48.

12 Sebastian Pompe, 2005, The Indonesian Supreme Court, A Study of Institutional Collaps, New York: Corrnel Sotheast Asia Program, hlm 413 
attorneys in specific cases. At the same time, there is no sense of shame for judges, attorney, police, and registrars to solicit money from lawyers. ${ }^{13} \mathrm{Hal}$ ini diperkuat dengan pengakuan seorang Hakim Agung dihadapan media masa pada tahun 1990 yang mengatakan

"Yes, I often get gifts from ligitants. If you call that corrupt, well indeed, then I must be corrupt. If I washn't, how do you think I could have a car and a home ?". ${ }^{14}$

Kerisauan masyarakat bukanlah sesederhana persoalan memberi dan menerima. Intinya persoalannya ialah adanya negosiasi isi putusan dalam pemberian dan penerimaan itu. Ini di catat dalam penelitian The World Bank sebagai berikut, "A postponed verdict is usually an invitation to begin negotiations with the judge. Even if a defendant has a strong case and good witness, there is no guarantee that justice will be done without paying". ${ }^{15}$

Berdasarkan penelitian The World Bank yang lain dilaporkan tentang adanya sebagian hakim yang menganggap tugasnya sebagai profit-driven industry atau bentuk usaha yang dapat diarahkan untuk mendapatkan keuntungan. ${ }^{16}$ Menurut Adi Sulistiyono, selain minus intelektual, perilaku hakim yang bermoral seperti ini merupakan wujud kontribusi hakim dalam proses krisis peradilan. Adi Sulistiyono yang mengadakan penelitian langsung di Pengadilan Negeri Semarang, Pengadilan Negeri Jakarta Pusat, dan Pengadilan Negeri Surabaya menemukan langsung proses negosiasi antara pencari keadilan dengan hakim dan menyimpulkan perbuatan-perbuatan seperti inilah yang membuat lembaga peradilan terperosok kedalam krisis. ${ }^{17}$ Kewibawaan lembaga peradilan meloncur kebawah, dan akhirnya menurut Todung Mulya Lubis, ketika Dato Param Cumaraswany, pelapor kasus PBB menyimpulkan bahwa

13 The World Bank, 2004, Combating Corruption in Indonesia, Enhancing Accountability for Development, Jakarta: The World Bank Office, hlm. 149

14 Sebastian Pompe, op cit, hlm. 415

15 The World Bank, op cit, hlm 150

16 Ali Budiardjo dkk, 1999, Diagnostic Assessment of Legal Development in Indonesia, Jakarta: Cyberconsult, $\mathrm{hlm}$. 144

17 Adi Sulistiyono, 2006, Krisis Lembaga Peradilan di Indonesia, Surakarta: UNS Press, hlm. 139 korupsi peradilan di Indonesia adalah salah satu yang terburuk di dunia, yang mungkin hanya bisa disamai Meksiko, mayoritas rakyat negeri ini tidak terkejut sama sekali. ${ }^{18}$

Timbulnya diskriminasi dalam penegakan hukum karena ajaran positivisme-legalistik beserta doktrin-doktrin dan asas-asas hukum yang mempertahankan paham liberalisme dan individualisme yang melatar-belakanginya memang dimaksudkan untuk lebih melindungi kemerdekaan individu daripada melindungi kepentingan rakyat/masyarakat luas. Akibatnya adalah sistem hukum memiliki ciri-ciri kelas (the class character of (aw) sebagaimana disebutkan oleh Donald Black.

Untuk memperoleh kebenaran substansial dengan keadilan sebagai unsur konstitutif (bukan unsur regulatif), maka pertanggungjawaban pidana, khususnya terhadap tindak pidana korupsi tidak terkecuali tindak pidana korupsi APBD yang dilakukan oleh anggota DPRD perlu direkonstruksi sistem hukumnya. Dasar rekonstruksi pertanggungjawaban pidana tersebut adalah Pasal 2 ayat (1) dan ayat (2) dan Pasal 5 UU No. 48 Tahun 2009.

Pasal 2 UU No. 48 Tahun 2009 menentukan sebagai berikut

(1) Peradilan dilakukan "DEMI KEADILAN BERDASARKAN KETUHANAN YANG MAHA ESA".

(2) Peradilan negara menerapkan dan menegakkan hukum dan keadilan berdasarkan Pancasila.

Pasal 5 UU No. 48 Tahun 2009 mengatur beberapa hal, yaitu

(1) Hakim dan hakim konstitusi wajib menggali, mengikuti, dan memahami nilai-nilai hukum dan rasa keadilan yang hidup dalam masyarakat.

(2) Hakim dan hakim konstitusi harus memiliki integritas dan kepribadian yang tidak tercela, jujur, adil, profesional, dan berpengalaman di bidang hukum.

(3) Hakim dan hakim konstitusi wajib menaati Kode Etik dan Pedoman Perilaku Hakim.

18 Todung Mulya Lubis, 2007, Mengapa Saya Mencintai Negeri ini, Jakarta: Buku Kompas, hlm. 143 
Mendasarkan Pasal 2 ayat (1) dan ayat (2) dan Pasal 5 UU No. 48 Tahun 2009, jelas bahwa rekonstruksi pertanggungjawaban pidana dan pertanggungjawaban administrasi adalah berkaitan dengan nilai-nilai keadilan, nilai-nilai ketuhanan dan nilai-nilai hukum yang hidup dalam masyarakat (the living law).

Salah satu bagian dari Kesimpulan Seminar Hukum Nasional ke-Vl/994, dinyatakan; "Perlu untuk dikembangkan gagasan mengenai kualitas pemberian keadilan (the dispension of justice) yang lebih cocok dengan sistem hukum Pancasila". Dari pernyataan inipun, tersimpul perlunya dikembangkan keadilan bercirikan Indonesia, yaitu “"keadilan Pancasila", yang mengandung makna "keadilan berketuhanan", "keadilan berkemanusiaan (humanistik)", "keadilan yang demokratik, nasionalistik, dan berkeadilan sosial". Ini berarti, keadilan yang ditegakkan juga bukan sekedar keadilan formal, tetapi keadilan substansial. ${ }^{19}$

\section{Jenis-jenis Putusan Mahkamah Agung}

Berdasarkan hasil penelitian terhadap 16 putusan MARI yang sudah mempunyai kekuatan hukum tetap, maka jenis putusan MARI dapat dikategorikan kedalam tiga keputusan. Tiga putusan tersebut adalah putusan pidana, putusan lepas, dan putusan bebas.

Ada lima putusan MARI yang berupa putusan dipidana (vrijspraak) yakni Putusan MARI No. $1838 \mathrm{~K} / \mathrm{Kr} / 2005$; Putusan MARI No. 1905K/ $\mathrm{Pid} / 2006$; Putusan MARI No. 2851K/Pid/2006; Putusan MARI No. 1702K/Pid/2007; dan Putusan MARI No. 365K/Pid.Sus/2008. Dasar pertimbangan hukum (ratio decidendi) putusanputusan MARI tersebut adalah sebagai berikut.

Pertama, nilai-nilai dalam PP No. 110 Tahun 2000 masih dipertahankan dalam PP No. 24 Tahun 2004 sehingga tidak ada perubahan perundang-undangan dimaksud Pasal 1 ayat (2)

19 Barda Nawawi Arief, 2010, Pendekatan Keilmuan dan Pendekatan Religius Dalam Rangka Optimalisasi dan Reformasi Penegakan Hukum (Pidana) di Indonesia, Semarang: Badan Penerbit Universitas Diponegoro, hlm 34. Baca juga A. Reni Widyastuti, "Penegakan Hukum: Mengubah Strategi dari Supremasi Hukum ke Mobilisasi Hukum untuk Mewujudkan Kesejahteraan dan Keadilan", Jurnal Hukum Pro Justitia Vol. 26 No. 3 Juli 2008 FH Unpar Bandung, hlm. 240-248.
KUHP; kedua, melanggar Pasal 56 ayat (1) Permendagri No. 2 Tahun 2004 bahwa perjalanan dinas keluar negeri harus mendapat ijin dari mendagri dan sebagian besar anggota DPRD melakukan perjalanan dinas fiktif; ketiga, menyalahgunakan kesempatan, kewenangan atau sarana yang ada padanya karena jabatan/ kedudukan sebagai pimpinan dan anggota DPRD, yakni penambahan penghasilan atau pendapatan dengan mengeluarkan SK Pimpinan DPRD; keempat, perbuatan terdakwa masih dalam lingkungan kewenangan dalam kapasitasnya sebagai Wakil Ketua DPRD dan sebagai anggota serta koordinator Panggar, yakni mengesahkan APBD sesuai dengan mekanisme yang berlaku dan seharusnya gubernur yang menjadi terdakwa karena gubernur adalah Pemegang Kekuasaan Umum Pengelolaan Keuangan Daerah (Pasal 1.4 jo Pasal 2 PP. No. 105 Tahun 2000); dan kelima mengeluarkan dana APBD yang melampaui batas tersedianya anggaran yang cukup sehingga melanggar Pasal 10 ayat (3) PP No. 105 Tahun 2000. "Pengelolaan Keuangan Daerah dilakukan secara tertib, efisien, efektif, dan bertanggungjawab dengan memperhatikan asas keadilan dan kepatutan".

MARI dalam putusan-putusan di atas berpendapat bahwa terdakwa telah memenuhi unsur-unsur Pasal 2 ayat (1) atau Pasal 3 UU No. 31 Tahun 1999. Dalam lima putusan ini, MARI hanya membuktikan adanya tindak pidana korupsi (criminal act). MARI tidak menganalisis unsur-unsur pertanggungjawaban pidana, terutama unsur-unsur mens rea secara lebih mendalam. Hal ini dibenarkan karena pertanggungjawaban pidana hanya terbatas pada masalah yang bersifat normatif dan tidak dirumuskan secara tegas dan jelas dalam perundang-undangan pidana materiil seperti dikatakan oleh Schaffmeister bahwa "penggunaan kesalahan sebagai dasar pemidanaan bukan keharusan menurut undang-undang yang empiris, tetapi asas normatif". ${ }^{20}$ Konsekuensinya adalah seolah-olah memang tidak ada standar dalam menentukan kesalahan dan pertanggungjawaban pidana. Hal demikian ini berdampak pada

20 Schaffmeister, D, Keijzer, $\mathrm{N}$ dan Sutorius, PH, 1995, Hukum Pidana, Yogyakarta: Liberty, hlm. 82 
tidak adanya pola yang seragam menentukan hal itu dalam setiap putusan pengadilan. ${ }^{21} \mathrm{Se}-$ benarnya Pembuktian tentang pertanggungjawaban pidana berarti harus membuktikan unsur-unsur petanggungjawaban pidana secara implisit tercantum dalam Pasal 183 KUHAP yang berbunyi: Hakim tidak boleh menjatuhkan pidana kepada seorang kecuali apabila dengan sekurang-kurangnya dua alat bukti yang sah, ia memperoleh keyakinan bahwa tindak pidana benar-benar terjadi dan bahwa terdakwalah yang bersalah melakukannya.

MARI dalam putusan-putusan tersebut di atas, mendasarkan pembuktian hanya terbatas pada tindak pidana korupsi adalah didasarkan kepada Putusan MARI No. 1352 K/Pid/1991 bahwa kesalahan terdakwa dipandang terbukti dengan sendirinya ketika seluruh unsur tindak pidana telah dapat dibuktikan. Putusan ini bertentangan dengan Pasal 183 KUHAP dan Asas Praduga Tak Bersalah (Penjelasan KUHAP).

Berbeda halnya apabila MARI mendasarkan pada Putusan MARI No. 14 K/Pid/1992, bahwa disamping tindak pidana yang didakwakan terbukti, juga mempertimbangkan kesengajaan terdakwa dalam menentukan pertanggungjawaban pidananya sekalipun dalam rumusan tindak pidana yang didakwakan, tidak terdapat 'dengan sengaja'. Ini berarti bahwa kesalahan terdakwa di pertimbangkan setelah dan di luar dari tindak pidana yang didakwakan.

Mendasarkan Putusan MARI No. $14 \mathrm{~K} / \mathrm{Pid} /$ 1992, maka MARI di samping membuktikan tindak pidana, juga harus membuktikan kesalahan terdakwa. Dengan perkataan lain MARI juga dibebani pembuktian adanya unsur mens rea. Apabila MARI konsisten dengan pendapatnya, sebenarnya (pada saat PP No. 105 Tahun 2000) bukan hanya anggota DPRD yang dimintai pertanggungjawaban pidana (walaupun di kalangan ahli hukum administrasi dan ahli hukum pidana masih menjadi kontroversi tentang pertanggungjawaban pidana anggota DPRD), tetapi

21 Chairul Huda, 2006, Dari Pidana Tanpa Kesalahan Menuju Kepada Tiada Pertanggungjawaban Pidana Tanpa Kesalahan, Jakarta: Fajar Interpratama Offset, hlm. 2 justru yang terutama adalah Sekretaris DPRD sebagai Pengguna Anggaran Daerah yang menerbitkan Surat Permintaan Pembayaran (Pasal 28 ayat 1), Kepala Daerah yang menerbitkan Surat Keputusan Otorisasi (Pasal 26) dan Pejabat Pengelola Keuangan Daerah yang menerbitkan Surat Perintah Membayar (Pasal 28 ayat 2). Hal ini menunjukkan adanya karakteristik kelas (the class character of law) sistim hukum nasional.

Ada tujuh putusan MARI yang berupa putusan lepas dari segala tuntutan hukum (ontslag van Rechtvervolging). Putusan lepas adalah apabila perbuatan yang didakwakan memenuhi rumusan delik tetapi perbuatan tersebut bukan merupakan kejahatan atau pelanggaran karena tidak terdapat unsur melawan hukumnya perbuatan. Sebagaimana diketahui, bahwa unsur melawan hukum adalah unsur mutlak untuk setiap tindak pidana. Yurisprudensi MARI No. 30 K/Kr/1969 menyatakan adanya dua hal, yaitu dalam setiap tindak pidana selalu ada unsur sifat melawan hukum dari perbuatan yang dituduhkan, walaupun dalam rumusan delik tidak selalu dicantumkan; dan tanpa adanya unsur sifat melawan hukum, tidak mungkin perbuatan yang dituduhkan merupakan suatu tindak pidana.

Adapun tujuh putusan MARI tersebut adalah Putusan MARI No. 521K/Pid.Sus/2007; Putusan MARI No. 491K/Pid.Sus /2007; Putusan MARI No. 93PK/Pid/2006; Putusan MARI No. 19PK/Pid.Sus /2008; Putusan MARI No. 20PK/ Pid.Sus/2008; Putusan MARI No. 1311K/Pid.Sus/ 2008; dan Putusan MARI No. 117K/Pid/2007.

Dasar pertimbangan hukum (ratio decidendi) MARI dalam putusan-putusan tersebut, antara lain adalah sebagai berikut. Pertama, penyusunan dan penetapan APBD merupakan tugas konstitusional anggota DPRD sebagai badan/anggota legislatif dan karena itu Hakim Pidana tidak dapat menilai tugas konstitusional tersebut; kedua, penetapan besarnya APBD beserta peruntukkannya adalah wewenang DPRD dan Pemerintah Daerah sesuai dengan kemampuan daerah masing-masing sehingga sekali pun memenuhi unsur Pasal 3 UU No. 31 Tahun 1999 akan tetapi bukan merupakan 
kajahatan atau pelanggaran; ketiga, tindakan DPRD bersama-sama dengan Pemerintah Daerah yang menyetujui dan mengesahkan RAPBD menjadi APBD dalam Sidang Pleno adalah tindakan "institutional collective collegial" dan karenanya adalah sah dan dapat dipertanggungjawabkan secara hukum; keempat, PP No. 110 Tahun 2000 bertentangan dengan peraturan perundang-undangan yang lebih tinggi, yakni Pasal 34 dan 39 UU No. 4 Tahun 1999 serta Pasal 19 dan Pasal 21 UU No. 22 Tahun 1999. Begitu juga halnya dengan PP No. 24 Tahun 2004 yang secara substansial materinya tidak jauh berbeda dengan PP No. 110 Tahun 2000 sehingga adagium "Lex posterior derogate legi priori" tidak berlaku bagi PP No. 24Tahun 2004 dan juga tidak terdapat perubahan perundang-undangan dimaksud Pasal 1 ayat 2 KUHP karena tidak ada "verandering in de rechtsovertuiging van de wetgever" (perubahan keyakinan / perasaan hukum dari pembentuk undang-undang); dan kelima, Perda APBD yang cacat hukum selama belum dibatalkan melalui lembaga review, maka Perda APBD tetap sah sebagai hukum positif.

Dari pertimbangan hukum tersebut di atas, MARI berpendapat bahwa, tindakan-tindakan anggota DPRD merupakan bentuk pelanggaran administrasi karena beberapa hal. Pertama, perbuatan anggota DPRD adalah perbuatan yang bertentangan dengan undang-undang cq peraturan perundang-undangan yang berkaitan dengan penyusunan Perda APBD; kedua, perbuatan anggota DPRD telah melanggar larangan detournement de pouvoir; ketiga, perbuatan anggota DPRD adalah perbuatan yang bertentangan dengan Asas-Asas Umum Pemerintahan yang Baik; dan keempat, tidak ada unsur mens rea.

Kiranya benar bahwa sumber hukum dalam penyusunan Perda APBD menurut I Gede Panca Astawa Guru Besar Hukum Administrasi Universitas Padjadjaran adalah Sidang Pleno DPRD. Dalam keterangannya sebagai ahli di Pengadilan Negeri Surakarta tanggal 02 Juli 2008 mengenai kasus korupsi dana APBD oleh anggota DPRD, beliau menyatakan : a. Laporan Pertanggungjawaban Kepala Daerah yang telah diterima dan telah disetujui DPRD (dalam Sidang Pleno DPRD dan Pemerintah Daerah) secara yuridis maupun secara politis sudah final. Apabila terjadi penyimpangan, seharusnya pada saat pembahasan anggaran hal itu dikoreksi.

b. Kalau tidak dikoreksi pada saat perubahan anggaran, secara yuridis sudah tidak ada masalah.

c. Perbuatan para terdakwa (enam anggota DPRD Kota Surakarta) masuk dalam wilayah hukum administrasi dan bukan dipaksakan ke dalam wilayah hukum pidana.

d. Institusi yang mempunyai kewenangan untuk bertindak sebagai auditor negara hanyalah BPK.

e. BPKP hanya sebagai penunjang. Itupun kalau diminta BPK. Apabila ada indikasi unsur pidana, BPKP hanya melakukan investigasi, sedangkan yang menilai dan menetapkan kerugian keuangan negara/ daerah adalah BPK (UU No. 15 Tahun 2004 jo UU No. 15 Tahun 2006).

Keterangan I Gede Panca Astawa di atas adalah tidak jauh berbeda dengan pendapat Indriyanto Seno Adji yang menyatakan bahwa

sering kali penegak hukum memahami secara menyimpang terhadap soal "administrative rechtelijk" dari ranah Hukum Administrasi Negara yang dianggap sebagai tindak pidana korupsi. Perhatikan saja pemidanaan terhadap perkaraperkara antara lain Akbar Tandjung (meskipun terlepas dari segala tuntutan hukum oleh Mahkamah Agung), Syahrir Sabirin (dibebaskan dari segala dakwaan oleh Mahkamah Agung), Samadikun, tiga mantan Direktur Bank Indonesia, Direksi Bank Mandiri (Nelloe Cs), Khususnya dalam kaitan antara Hukum Pidana dari unsur "menyalahgunakan wewenang" (Pasal 1 ayat 1 b UU No. 3 Tahun 1971 jo Pasal 3 UU No. 31 Tahun 1999) dan Hukum Administrasi Negara yang berkaitan antara "Staatsbeleid" (Kebijakan Negara) dengan Asas-Asas Umum Pemerintah yang Baik (Algemene Beginselen van Behoorlijk Bestuur). Badan yudikatif telah mencampuradukkan, bahkan menganggap sama antara unsur "menyalahgunakan wewenang" dan "melawan hukum", bahkan, tanpa disadari bahwa peradilan menerapkan asas perbuatan melawan hu- 
kum materiel dengan fungsi positif tanpa memberikan kriteria yang jelas untuk menerapkan asas tersebut, yaitu melakukan pemidanaan berdasarkan asas kepatutan dengan menyatakan para pelaku telah melanggar asas-asas umum pemerintahan yang baik, tanpa bisa membedakannya dengan persoalan "beleid" yang tunduk pada Hukum Administrasi $\mathrm{Ne}$ gara. ${ }^{22}$

Dari pertimbangan-pertimbangan hukum dalam putusan-putusan MARI di atas jelas bahwa pertimbangan hukum lebih banyak bersumber pada peraturan perundang-undangan yang berlaku, Asas-Asas Umum Pemerintahan yang Baik (AAUPB) dan pelanggaran larangan detournement de pouvoir, tanpa menganalisis aspek sikap batin (mens rea) anggota DPRD. Dengan perkataan lain bahwa MARI mengabaikan analisis tentang unsur-unsur mens rea yang menjadi dasar pertanggungjawaban pidana dan unsur melawan hukum yang merupakan unsur mutlak setiap tindak pidana. MARI tidak memperhatikan "kepentingan hukum" yang dilindungi Pasal 2 dan Pasal 3 UU No. 31 Tahun 1999, yakni kerugian keuangan negara/ perekonomian negara yang apabila dibiarkan akan menghambat pertumbuhan dan kelangsungan pembangunan nasional yang menuntut efisiensi tinggi sebagaimana tersebut dalam Konsiderans UU No. 31 Tahun 1999. Dari Konsideran ini kemudian diketahui bahwa tindak pidana korupsi merupakan Extra Ordinary Crime. $^{23}$

Ada 4 (empat) putusan yang dapat digolongkan sebagai putusan bebas. Keempat putusan bebas itu adalah Putusan MARI No. 487K/ Pid/2007; Putusan MARI No. 1862K/Pid/2007; Putusan MARI No. 1001K/Pid/2007; dan Putusan MARI No. 1626K/Pid/2007. Dasar pertimbangan

22 Indriyanto Seno Adji. Prospek Hukum Pidana Indonesia pada Masyarakat Yang Mengalami Perubahan. Pidato Upacara Pengukuhan Sebagai Guru Besar tetap Dalam Ilmu Hukum Pidana pada Fakultas Hukum Universitas Krisnadwipayana, Jakarta: 19 Februari 2004. hlm. 27

23 Bandingkan pendapat ini dengan pemikiran rule breaking yang diintrodusir oleh Satjipto Rahardjo. Lihat dalam Yohanes Suhardin, "Paradigma Rule Breaking dalam Penegakan Hukum yang Berkeadilan", Jurnal Hukum Pro Justitia Vol. 26 No. 3 Juli 2008 FH Unpar Bandung, hlm. 282-293. hukum (ratio decidendi) MARI dalam putusanputusan tersebut adalah sebagai berikut.

Pertama, tindakan-tindakan anggota DPRD menyusun Perda APBD merupakan tindakan yang sah dan dapat dipertanggung jawabkan secara hukum dengan alasan sebagai berikut: (a) Penyimpangan Perda APBD terhadap peraturan perundang-undangan yang menjadi dasar dari penyusunan APBD adalah menjadi tanggung jawab DPRD dan Pemda sebagai pihak yang menyetujui dan mengesahkan Perda APBD; (b) Perda APBD disusun sesuai dengan prosedur hukum yang berlaku dan oleh karena itu Perda APBD adalah sah berlaku sebagai hukum positif; (c) Terhadap Perda yang cacat hukum, selama belum dibatalkan melalui lembaga review, Perda APBD tetap sah menjadi hukum positif; (d) Pengujian Perda APBD melalui lembaga review adalah di luar kewenangan Pengadilan dan oleh karena itu Pengadilan tidak dibenarkan melakukan uji materiil terhadap Perda APBD; (e) Wewenang untuk menguji (formal dan material) terhadap Perda APBD adalah Mahkamah Agung melalui judicial review. Sejak berlakunya UU No. 32 Tahun 2004 yang mempunyai kewenangan menguji Perda adalah Presiden dengan Peraturan Presiden dan MARI dengan Judicial Review (Pasal 145); (f) PP No. 105 Tahun 2000 adalah produk hukum yang bersifat administratif karena substansi aturan dan pasal-pasal sepenuhnya berada dalam lingkup hukum administrasi; (g) Penyimpangan penggunaan kewenangan menurut PP No. 105 Tahun 2000 diancam dengan sanksi administratif, yaitu hukuman untuk mengembalikan dan untuk mengganti kerugian daerah sebagai akibat dari perbuatan melanggar hukum atau akibat dari kelalaian pihak manapun. (Pasal 44 dan Pasal 45 PP No. 105 Tahun 2000); (h) Perbuatan yang dilakukan oleh anggota DPRD adalah produk hukum yang bersifat institutional collectif collegial yang merupakan penjabaran terhadap kebijakan pemerintah atas dasar UU No. 2 Tahun 1999; (i) Karena produk hukum yang bersifat institutional collective collegial, maka adalah menjadi tanggung jawab bersama Pemerintah Daerah dan DPRD dan bukan tanggung jawab individu masing-masing anggota 
DPRD dan individu pemerintah daerah yang bersangkutan; dan (j) Karena Perda APBD adalah sah sebagai hukum positif, maka tidak ada unsur melawan hukum pada diri anggota DPRD yang melaksanakan Perda APBD dan oleh karena itu perbuatan anggota DPRD tidak memenuhi unsur-unsur Pasal 2 ayat (1) dan Pasal 3 UU No. 31 Tahun 1999.

Kedua, berdasarkan butir a sampai $\mathrm{j}$ di atas maka perbuatan DPRD dalam menyusun Perda APBD dapat dipertanggungjawabkan secara hukum karena Perda APBD telah disusun sesuai dengan prosedur hukum yang berlaku.

Sama seperti halnya dengan putusanputusan MARI yang berupa putusan lepas. MARI berpendapat bahwa pelanggaran terhadap peraturan perundang-undangan yang menjadi dasar bagi penyusunan Perda APBD adalah pelanggaran yang bersifat administratif. Sementara Perda APBD telah disahkan sesuai dengan mekanisme prosedur hukum yang berlaku. Dengan demikian apabila Perda APBD itu cacat hukum (karena melanggar peraturan perundang-undangan yang menjadi dasar penyusunan Perda APBD) maka Perda APBD tetap sah sebagai hukum positif sampai dibatalkan melalui lembaga review. Ini berarti, bahwa tindakan anggota DPRD menyusun Perda APBD tersebut adalah bukan merupakan perbuatan melawan hukum dan tidak memenuhi unsur-unsur Pasal 2 ayat (1) dan Pasal 3 UU No. 31 Tahun 1999.

Sama halnya dengan putusan-putusan lepas, MARI sama sekali tidak menganalisis unsur-unsur mens rea atau unsur-unsur culpa in causa (yang mungkin ada) pada diri anggota DPRD. MARI tidak menganalisis tiga asas hukum penting yang selalu muncul dalam rangka alasan penghapus pidana, yakni asas subsidiaritas yang berisi secara singkat tidak ada alternatif untuk perbuatan yang dapat dipidana; asas proporsionalitas yang berisi secara singkat harus diusahakan keseimbangan antara tujuan dan sarana; dan asas culpa in causa yang mengimplikasikan pertanggungjawaban pidana bagi orang yang sejak semula mengambil risiko bahwa dia akan melakukan perbuatan pidana. ${ }^{24}$

Asas Culpa in causa dimungkinkan melekat pada diri masing-masing anggota DPRD. Sejak semula (penyusunan draft APBD, khususnya pos anggaran belanja DPRD dan sekretariat DPRD yang dikoordinir oleh Panitia Anggaran yang pada umumnya diketuai oleh Ketua DPRD), anggota DPRD bersama-sama dengan Pemerintah Daerah telah bersepakat untuk melanggar peraturan perundang-undangan yang menjadi dasar penyusunan APBD.

\section{Kuatnya Ajaran Positivisme-Legalistik dalam Dunia Peradilan}

Apabila dicermati pertimbangan-pertimbangan hukum (ratio decidendi) dalam putusan-putusan MARI yang berupa pidana, lepas dan putusan bebas nampak bahwa pertanggungjawaban pidana dan pertanggungjawaban administrasi dalam hal tindak pidana korupsi APBD oleh anggota DPRD adalah berkaitan dengan masih kuatnya ajaran positivisme-legalistik. Hal ini dapat dilihat dari pertimbanganpertimbangan hukum MARI yang mendasarkan pada beberapa hal.

Pertama, keberadaan PP No. 110 Tahun 2000 dan PP No. 24 Tahun 2004 dalam hubungannya dengan perubahan perundang-undangan Pasal 1 ayat (2) KUHP. Kedua, keberadaan PP No. 105 Tahun 2000 yang menimbulkan perbedaan pendapat tentang norm adressat PP No. 105 Tahun 2000. Ketiga, Perda APBD yang merupakan produk hukum yang bersifat institutional collective collegial. Keempat, keberadaan Peraturan Tata Tertib DPRD yang diamanatkan oleh Pasal 34 UU No. 4 Tahun 1999 dan Pasal 19 UU No. 22 Tahun 1999 bahwa pelaksanaan hakhak DPRD diatur dalam Peraturan Tata Tertib.

Kelima, penyelesaian secara administratif dalam wujud tuntutan ganti kerugian daerah dalam hal terjadi perbuatan melanggar hukum atau kelalaian dalam Pasal 44 dan Pasal 45 PP No. 105 Tahun 2000. Keenam, keberadaan Kepmendagri No. 29 Tahun 2002 sebagai peraturan pelaksanaan dari PP No. 105 Tahun 2000 yang

24 Sahetapy, J.E, 1995, Hukum Pidana, Jakarta: Konsorsium Ilmu Hukum Departemen P\&K, hlm. 74-75. 
ditujukan kepada Pemerintah Daerah dan bukan untuk DPRD. Ketujuh, pendapat Pengadilan bahwa pengadilan tidak mempunyai kewenangan untuk menguji (review) keabsahan Perda.

Perbedaan cara menafsirkan keberadaan peraturan perundang-undangan tersebut di atas menjadi sumber timbulnya putusan-putusan pengadilan yang tidak sama yang merupakan bentuk pertanggungjawaban pidana dan pertanggungjawaban administrasi terhadap tindak pidana korupsi APBD oleh anggota DPRD. Dilain pihak penafsiran terhadap perundang-undangan tersebut adalah menjadi wewenang mutlak Pengadilan. Atas dasar itu adalah benar apabila Satjipto Raharjo menilai bahwa putusan pengadilan sudah bergeser ke arah kediktatoran pengadilan (judicial dictatorship). Pengadilan lebih menyuarakan kepentingan elit politik dan elit ekonomi dari pada menyuarakan golongangolongan yang unrepresented dan under-represented. ${ }^{25}$ Kenyataan ini dibenarkan oleh Francis Fukuyama yang mengatakan bahwa

"Any people intuitively belive that capitalism is bad for moral life. Markets put a price on everything and replace human relationships with the bottom line. By this view, a modern capitalist society consumes more social capital than it produces. Capitalist societies are destined to become materially wealthier but morally poorer". ${ }^{26}$

Keadaan demikian ini adalah tidak terlalu salah karena dua hal. Pertama, Putusan MARI No. 1352 K/Pid/1991 bahwa kesalahan terdakwa dipandang terbukti dengan sendirinya ketika seluruh unsur tindak pidana telah dapat dibuktikan. Putusan ini bertentangan dengan Pasal 183 KUHAP dan Asas Praduga Tak Bersalah. Kedua, ajaran positivisme-legalistik menganut falsafah liberalisme, individualisme dan rationalisme. Akibat yang terjadi adalah putusanputusan pengadilan (MARI) menjadi tercabut dari akarnya, yaitu nilai-nilai keadilan, ketuhanan dan nilai-nilai yang hidup dalam masyarakat (the living law) sebagaimana diama-

25 Satjipto Rahardjo, op.cit. hlm 38

26 Francis Fukuyama, 1999, The Great Disruption: Human Nature and The Reconstitution of Social Order. USA; The Free Press, hlm. 249 natkan Pasal 2 dan Pasal 5 UU No. 48 Tahun 2009. Akibat lebih lanjut adalah timbulnya ketidak percayaan akan keefektifan sistem hukum seperti dinyatakan Kongres VI PBB :

"Acapkali, ketiadaan konsistensi antara undang-undang dengan kenyataan merupakan faktor kriminogen: semakin jauh UU bergeser dari perasaan dan nilai-nilai yang hidup di dalam masyarakat, semakin besar ketidakpercayaan akan keefektifan sistem hukum itu". (Often, lack of consistency between laws and reality was criminogenic: the farther the law was removed from the feeling and the values shared by the community, the greater was the lack oconfidence and tust in the efficacy of the legal system).

Sejalan dengan pernyataan Kongres $\mathrm{VI}$ PBB di atas, Robert C. Ellickson menyatakan, "Law makers who are unappreciative of the social conditions that foster informal cooperation are likely to create a world in which there is both more law and less order". ${ }^{27}$

Asas legalitas yang dipandang sebagai "lex scripta","lex certa", dan "lex stricta" mendapat kritik dari Marjanne Termorshuizen dengan antara lain mengemukakan: "the view that a lex scripta can be certa, that is to say certain, in the sense of unambiguous, cannot be maintained. There is no such thing as a legal provision which is clear and unambiguous in all circumstances". (Pandangan bahwa hukum tertulis itu jelas dan pasti, dalam arti tidak ambigius, tidak dapat dipertahankan. Tidak ada suatu ketentuan hukum yang jelas dan tidak ambigius dalam semua keadaan). ${ }^{28}$

Untuk itu diperlukan rekonstruksi pertanggungjawaban pidana dan pertanggungjawaban administrasi yang sesuai dengan kerangka sistem hukum nasional Indonesia yang berorientasi pada keadilan yang bercirikan Indonesia, yaitu Keadilan Pancasila. Keadilan Pancasila mengandung makna "keadilan berketuhanan", keadilan berkemanusiaan (humanistik)", "keadilan yang demokratik, nasionalistik,

27 Robert C. Ellickson, 1991, Order Without Law : How Neighbors Settle Disputes, Cambridge: Harvard University Press, hlm : 286.

28 Barda Nawawi Arief, Pendekatan Keilmuan....op.cit $\mathrm{Hlm}: 16$. 
dan berkeadilan sosial". Ini berarti, keadilan yang ditegakkan juga bukan sekedar keadilan formal, tetapi keadilan substansial. ${ }^{29}$

\section{Perluasan Makna Asas Legalitas dengan Ke- bijakan Legislatif.}

Perluasan makna asas legalitas dengan kebijakan legislatif dilakukan dengan beberapa cara. Pertama. penerapan asas Afwezigheid van Alle materiele Wederrechtelijkheid (AV$A W)$. Dalam doktrin hukum pidana dikenal apa yang disebut AVAW (Afwezigheid Van Alle materiele Wederrechtelijkheid) yang merupakan perwujudan dari nilai-nilai sosio-kultural masyarakat. Dengan demikian adalah dipertanyakan Putusan Mahkamah Konstitusi No. 003/PUU-IV/2006 yang mencabut pengertian melawan formil dan materiil dalam Penjelasan Pasal 2 ayat 1 UU No. 31 Tahun 1999 dan kemudian diganti dengan pengertian melawan hukum formil. Dengan pengertian melawan hukum formil berarti melawan hukum terlepas dari akar nilai-nilai kontekstual kultural dan religius dalam kehidupan bermasyarakat.

Kedua, perluasan makna asas legalitas dari makna kepastian formal ke arah kepastian materiil yang memberi kemungkinan kepada hukum yang hidup (hukum tidak tertulis) sebagai sumber hukum pidana. Dengan demikian sumber hukum pidana tidak hanya sumber hukum formil tetapi juga sumber hukum materiil. Apabila hukum diartikan sebagai "ius" (keadilan sebagai unsur konstitutif) dan bukan diartikan sebagai "lex" (keadilan sebagai unsur regulatif), maka asas legalitas tidak hanya diartikan sebagai Nullum delictum sine lege, tetapi juga Nullum delictum sine ius.

Ketiga, sebagai konsekuensi diterimanya nilai-nilai yang bersumber pada hukum adat dan hukum yang hidup dalam masyarakat, maka di samping dapat menjadi sumber hukum yang bersifat positif, nilai-nilai yang bersumber pada hukum adat dan hukum yang hidup dalam masyarakat dapat berfungsi sebagai sumber hukum yang bersifat negatif, dalam arti bahwa, nilai-nilai tersebut dapat dijadikan alasan

\footnotetext{
${ }^{29}$ Barda Nawawi Arief. op.cit. hlm 34
}

pembenar (rechtvaardigingsgrond) yang menghapuskan sifat melawan hukumnya perbuatan atau dapat berfungsi sebagai alasan-alasan yang memperingan pemidanaan (mitigating circumstance), dan sebaliknya mungkin justru menjadi alasan yang memberatkan pemidanaan (aggravating circumstance). Di dalam kondisi yang sangat pluralistik dan sebagian besar penduduk masih hidup di daerah pedesaan, kiranya sangat bijaksana untuk menempatkan asas-asas keadilan yang bersifat umum sebagai pasangan dari kepastian hukum. ${ }^{30}$

\section{Rekonstruksi Sistem Peradilan Pidana}

Rekonstruksi sistem peradilan pidana dilakukan dengan optimalisasi tiga pendekatan keilmuan secara integral. Ketiga pendekatan tersebut adalah sebagai berikut. Pertama, pendekatan juridis keilmuan religius, yakni pendekatan yang berorientasi/berpedoman pada "ilmu" (hukum pidana) dan "tuntunan Tuhan" dalam menegakkan hukum pidana positif. Pendekatan ini disebut pendekatan ilmu hukum.

Asas juridis religius ini ditegaskan dalam (a) Pasal 2 ayat (1) dan ayat (2) UU No. 48 Tahun 2009 yang mengatur tentang Peradilan dilakukan "DEMI KEADILAN BERDASARKAN KETUHANAN YANG MAHA ESA" dan Peradilan negara menerapkan dan menegakkan hukum dan keadilan berdasarkan Pancasila; (b) Pasal 8 ayat (3) UU Kejaksaan No. 16 Tahun 2004 yang menyebutkan bahwa "Demi keadilan dan kebenaran berdasarkan Ketuhanan Yang Maha Esa, jaksa melakukan penuntutan dengan keyakinan berdasarkan alat bukti yang sah".

Berdasarkan Pasal 8 (3) UU Kejaksaan No. 16 Tahun 2004 berarti bahwa tidak ada sekulerisme dalam penegakan hukum di Indonesia; penegakan hukum dan keadilan tidak hanya didasarkan pada tuntunan UU, tetapi juga harus berdasarkan "tuntunan

30 Muladi, 1990, Proyeksi Hukum Pidana Materiil Indonesia Di Masa Mendatang, Pidato Pengukuhan Guru Besar Ilmu Hukum Pidana Fakultas Hukum Undip tanggal 24 Pebruari 1990, hlm 17. Lihat dan bandingkan dengan RB Budi Prastowo, "Delik Formil/Materiil, Sifat Melawan Hukum Formil/Materiil dan Pertanggungjawaban Pidana Korupsi”, Jurnal Hukum Pro Justitia Vol. 24 No. 3 Juli 2006 FH Unpar Bandung, hlm. 212-226. 
Tuhan". Tidaklah ada artinya penegakan hukum pidana atau penjatuhan pidana berdasar tuntunan UU, apabila tidak memperhatikan prinsip-prinsip keadilan menurut tuntunan Tuhan.

Tuntunan Tuhan dalam penegakan keadilan (dalam pandangan Islam), antara lain terlihat dalam Al-Qur'an (An-Nissa': 58: apabila kamu menghukum di antara manusia, maka hukumlah dengan adil; An-Nissa':138 : Jadilah kamu orang yang benar-benar menegakan keadilan, menjadi saksi karena Allah, walaupun terhadap dirimu sendiri, ibu bapakmu dan kaum kerabatmu; dan Janganlah kamu mengikuti hawa nafsumu karena ingin menyimpang dari kebenaran/keadilan; Al-Maidah: 8: Janganlah kebencianmu kepada suatu kaum/golongan, mendorong kamu berlaku tidak adil; Asy-Syuura: 15: Perlakuan adil wajib ditegakkan terhadap siapa saja, kendati terhadap orang yang tidak seagama; dan Al-Maidah: 42 : Dan jika kamu memutuskan perkara mereka (orang Yahudi), maka putuskanlah (perkara itu) di antara mereka dengan adil, sesungguhnya Allah menyukai orang-orang yang adil").

Kedua, pendekatan juridis kontekstual kultural, yakni penegakan hukum pidana positif harus berada dalam konteks ke-Indonesia-an (dalam konteks sistem hukum nasional/national legal framework), dan bahkan dalam konteks pembangunan nasional dan pembangunan hukum nasional.

Pendekatan ini dapat dilakukan selain pada tahap legislasi/formulasi (law making) juga dapat dilakukan pada tahap aplikasi/ judisial (law enforcement). Dasar hukum pendekatan juridis kontekstual kultural adalah Pasal 5 UU No. 48 Tahun 2009.

Ketiga, pendekatan juridis berwawasan global/komparatif. Pendekatan pemikiran hukum yang berorientasi pada wawasan global/ komparatif memang pada umumnya diperlukan dalam masalah "pembaharuan hukum" (law reform), khususnya dalam "pembuatan UU" (kebijakan legislatif/formulasi). Dasar pemikiran pendekatan ini adalah berlakunya asas nasional aktif Pasal 5 ayat (1) ke-2 KUHP; adanya beberapa ketentuan dalam UU di luar KUHP yang memperluas jurisdiksi teritorial ke luar wilayah Indonesia (a.l. Pasal 97 UU Narkotika; Pasal 16 UU TPK; Pasal 3 (1) dan Pasal 4 UU Terorisme; Pasal 7 UU Pencurian Uang; Pasal. 2 UU-ITE No. 11/2008; dan banyaknya undangundang yang telah meratifikasi berbagai ketentuan/dokumen internasional. Khusus untuk tindak pidana korupsi UU No. 7 Tahun 2006 telah meratifikasi UNCAC-United Nations Convention Against Corruption, 2003.

Konsideran UU No. 7 Tahun 2006 menyebutkan bahwa tindak pidana korupsi tidak lagi merupakan masalah lokal, kana tetapi merupakan fenomena transnasional yang mempengaruhi seluruh masyarakat dan perekonomian sehingga penting adanya kerja sama internasional untuk pencegahan dan pemberantasannya termasuk pemulihan atau pengembalian aset-aset hasil tindak pidana korupsi; bahwa kerja sama internasional dalam pencegahan dan pemberantasan tindak pidana korupsi perlu didukung oleh integritas, akuntabilitas, dan manajemen pemerintahan yang baik; dan bahwa bangsa Indonesia telah ikut aktif dalam upaya masyarakat internasional untuk mencegah dan pemberantasan tindak pidana korupsi dengan telah menandatangani United Nation Convention Against Corruption, 2003. ${ }^{31}$

Dasar pemikiran lain diterapkannya pendekatan global adalah pendapat Barda Nawawi Arief, bahwa dengan pendekatan berwawasan global/komparatif dapat membawa sikap kritis terhadap sistem hukum sendiri dan dapat juga untuk pemecahan masalah-masalah hukum secara adil dan tepat. ${ }^{32}$

\section{Penutup \\ Simpulan}

Ada dua simpulan yang dapat diberikan berdasarkan permasalahan dan pembahasan tersebut di atas. Pertama, pertanggungjawaban pidana terhadap tindak pidana korupsi APBD oleh anggota DPRD dalam putusan-putusan pe-

\footnotetext{
31 Lihat dan bandingkan dengan Teguh Sulistia, “Konsep Efektif Hukum dalam Upaya Pemberantasan Korupsi, Kolusi dan Nepotisme di Indonesia", Jurnal Hukum Pro Justitia Tahun XXIII No. 2 April 2005 FH Unpar Bandung, hlm.23-39.

32 Barda Nawawi Arief, op.cit. hlm 40
} 
ngadilan masih mempertahankan ajaran positivisme-legalistik dengan falsafah liberalisme, individualisme dan rationalisme (warisan KUHP Belanda) sehingga ratio decidendi yang di jadikan dasar menjatuhkan putusan tidak dapat dipertahankan lagi karena menimbulkan tiga putusan yang berbeda secara substansial.

Kedua, perlu rekonstruksi pertanggungjawaban pidana yang disesuaikan dengan sistem hukum nasional dengan mendasarkan pada Pasal 2 dan Pasal 5 UU No. 48 Tahun 2009, yakni, (a) perluasan makna asas legalitas ke arah kepastian hukum material dengan keadilan substansial dengan memasukkan nilai-nilai hukum yang hidup dalam masyarakat baik dalam fungsi positif maupun fungsi negatif ("AVAW"). Dengan perkataan lain kepastian hukum material dengan keadilan yang berbasis pada nilainilai Pancasila; dan (b) pembaharuan Sistem Peradilan Pidana dengan berorientasi pada 3 (tiga) pendekatan secara integral, yakni: pendekatan juridis ilmiah religius; pendekatan juridis kontekstual kultural; pendekatan juridis berwawasan global/komparatif.

\section{Daftar Pustaka}

Pro Justitia. “Deep Ecology dalam Pengkajian Ilmu Hukum". Jurnal Hukum Pro Justitia. Vol. 27 No. 2. Oktober 2009. Bandung: FH Unpar;

Adji, Indriyanto Seno.2004. Prospek Hukum Pidana Indonesia pada Masyarakat Yang Mengalami Perubahan. Pidato Upacara Pengukuhan Sebagai Guru Besar tetap Dalam Ilmu Hukum Pidana pada Fakultas Hukum Universitas Krisnadwipayana. Jakarta: 19 Februari;

Ali Budiardjo dkk. 1999. Diagnostic Assessment of Legal Development in Indonesia. Jakarta: Cyberconsult;

Ali, Achmad. 2002. Keterpurukan Hukum di Indonesia. Jakarta: Ghalia Indonesia;

Arief, Barda Nawawi. 2010. Pendekatan Keilmuan dan Pendekatan Religius Dalam Rangka Optimalisasi dan Reformasi Penegakan Hukum (Pidana) di Indonesia. Semarang: Badan Penerbit Universitas Diponegoro;
Ellickson, Robert C. 1991. Order Without Law: How Neighbors Settle Disputes. Cambridge: Harvard University Press;

Friedmann, W. 1970. Legal Teory. New York: Columbia University Press;

Fukuyama, Francis. 1999. The Great Disruption: Human Nature and The Reconstitution of Social Order. USA; The Free Press;

Hartanti, E. 2007. Tindak Pidana Korupsi. Jakarta: Sinar Grafika;

Huda, Chairul. 2006. Dari Pidana Tanpa Kesalahan Menuju Kepada Tiada Pertanggungjawaban Pidana Tanpa Kesalahan. Jakarta: Fajar Interpratama Offset;

Huijbers, Theo. 1990. Filsafat Hukum. Yogyakarta: Kanisius;

J E, Sahetapy. 1995. Hukum Pidana. Jakarta: Konsorsium Ilmu Hukum Departemen P\&K;

Lubis, Todung Mulya. 2007. Mengapa Saya Mencintai Negeri ini. Jakarta: Buku Kompas;

Muladi. 1990. Proyeksi Hukum Pidana Materiil Indonesia Di Masa Mendatang. Pidato Pengukuhan Guru Besar IImu Hukum Pidana Fakultas Hukum Undip tanggal 24 Pebruari;

Mulyati, Lilik. 2008. Politik Hukum Kebijakan Legislasi Pembalikan Beban Pembuktian Dalam Tindak Pidana Korupsi. Dalam Buku Berjudul: Bagir Manan Ilmuan dan Penegakan Hukum (Kenangan Sebuah Pengabdian). Jakarta: Mahkamah Agung $\mathrm{RI}$;

Nurdjana, IGM. 2010. Sistem Hukum Pidana dan Bahaya Laten Korupsi: Perspektif Tegaknya Keadilan Melawan Mafia Hukum. Yogyakarta: Pustaka Pelajar;

Pompe, Sebastian. 2005. The Indonesian Supreme Court, A Study of Institutional Collaps. New York: Corrnel Sotheast Asia Program;

Prastowo, RB Budi. "Delik Formil/Materiil, Sifat Melawan Hukum Formil/Materiil dan Pertanggungjawaban Pidana Korupsi". Jurnal Hukum Pro Justitia. Vol. 24 No. 3. Juli 2006. Bandung: FH Unpar;

Rahardjo, Satjipto. 2008. Membedah Hukum Progresif. Jakarta: Penerbit Buku Kompas;

Rasul, Sjahruddin. "Penerapan Manajemen Berbasis Kinerja dalam Pemberantasan 
Korupsi”. Jurnal Hukum Pro Justitia. Vol. 26 No. 1. Januari 2008. Bnadung: FH Unpar;

Schaffmeister, dkk. PH. 1995. Hukum Pidana. Yogyakarta: Liberty;

Shafrudin. "Pelaksanaan Politik Hukum Pidana dalam Penegakan Hukum Pidana di Indonesia". Jurnal Hukum Pro Justitia. Vol. 27 No. 2. Oktober 2009. Bandung: FH Unpar;

Sina, La. "Dampak dan Upaya Pemberantasan serta Pengawasan Korupsi di Indonesia". Jurnal Hukum Pro Justitia. Vol. 26 No. 1. Januari 2008. Bandung: FH Unpar;

Sudarto. 1986. Hukum dan Hukum Pidana. Bandung: Alumni;

Suhardin, Yohanes. "Paradigma Rule Breaking dalam Penegakan Hukum yang Berkeadilan". Jurnal Hukum Pro Justitia. Vol. 26 No. 3. Juli 2008. Bandung: FH Unpar;

Sulistia, Teguh. "Konsep Efektif Hukum dalam Upaya Pemberantasan Korupsi, Kolusi dan Nepotisme di Indonesia". Jurnal Hukum
Pro Justitia. Tahun 23 No. 2. April 2005. Bandung: FH Unpar;

Sulistiyono, Adi. 2006. Krisis Lembaga Peradilan di Indonesia. Surakarta: UNS Press;

Syafrudin, Ateng. "Tanggung Jawab Kepala Daerah Menurut UU No 22 Tahun 1999". Majalah Hukum Pro Justitia. Tahun 19 No. 1. Januari 2001. Bandung: FH Unpar;

The World Bank. 2004. Combating Corruption in Indonesia, Enhancing Accountability for Development. Jakarta: The World Bank Office;

Widyastuti, A Reni. "Penegakan Hukum: Mengubah Strategi dari Supremasi Hukum ke Mobilisasi Hukum untuk Mewujudkan Kesejahteraan dan Keadilan". Jurnal Hukum Pro Justitia. Vol. 26 No. 3. Juli 2008. Bandung: FH Unpar;

Winarta, Frans Hendra. "Korupsi dan Hukum di Indonesia". Majalah Hukum Pro Justitia. Tahun 19 No. 3. Juli 2001. Bandung: FH Unpar. 